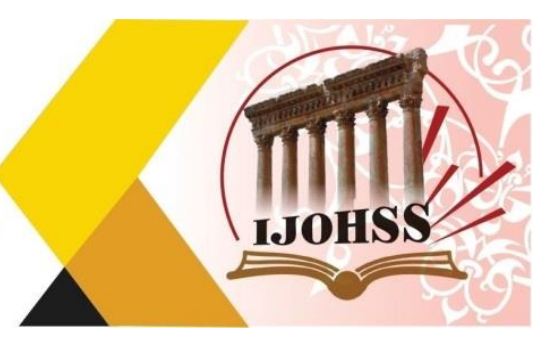

\title{
Ethical Leadership and Organisational Discipline: A Case Study on a Telecommunication Organisation in Oman
}

\author{
Moath Nagib Gharib \\ Assistant Professor \\ College of Commerce and Administrative Sciences \\ Dhofar University \\ Sultanate of Oman \\ Emil: mnagib@du.edu.om
}

\begin{abstract}
This study aims to explore the impact of ethical leadership dimensions (ethical role modelling, reward and punishment, and communicating about ethics and values) on organisational discipline in Omantel, a telecommunication organisation in Oman. Using random sampling, data was collected from employees working at Omantel, Dhofar Governorate. Additionally, a multiple regression analysis was used to investigate the impact of ethical leadership on organisational discipline. The study's results showed that only two dimensions of ethical leadership, namely ethical role modelling and communicating about ethics and values, had an effect on organisational discipline, whereas reward and punishment had no significant effect on organisational discipline.
\end{abstract}

Keywords: Ethical leadership, organisational discipline, Omantel, Oman. 


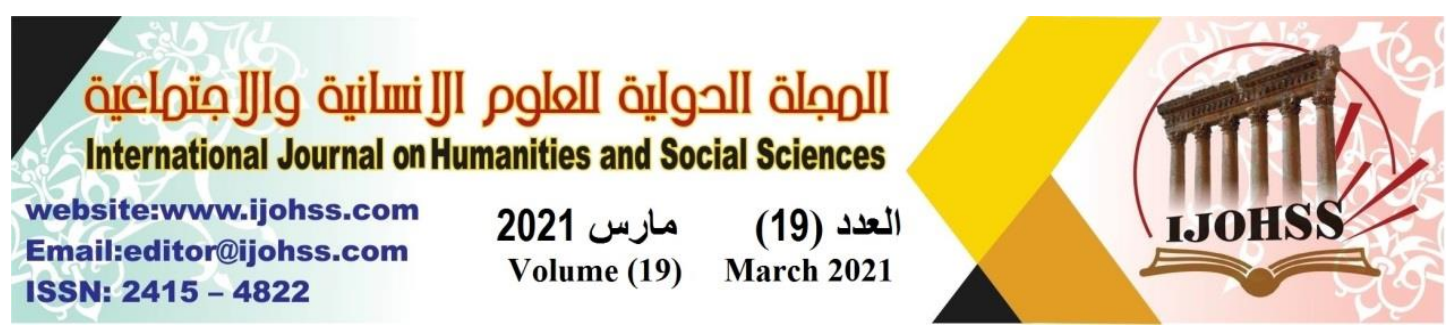

\section{INTRODUCTION}

There are differences in the literature regarding ethics in organisations (Brown \& Trevio, 2006), which is due to the increasing spread of business scandals and unethical practices both inside and outside the organisations (Colvin, 2003; Mehta, 2003; Mendonca, 2001). This suggests that qualified leaders armed with good morals are necessary (Dradkeh \& Al-Mutairy, 2017).

Recent research showed how ethical leadership reduces destructive behaviours and immoral practices, such as absenteeism, organisational cronyism and integrity violations (Hassan et al., 2014; Huberts et al., 2007; Mayer et al., 2009; Riaz \& Zaman, 2018). On the other hand, research also revealed how ethical leadership enhances and positively affects healthy behaviours and activities, such as organisational commitment, job satisfaction, employee ethical behaviour (Lu \& Lin, 2014), total quality management (Ekriem, 2012), trust (Van den Akker et al., 2009), administrative creativity (Alshaier, 2017), organisational performance (Butt et al., 2016) and employee well-being (Rantika \& Yustina, 2017; Yang, 2014).

Organisations can survive, grow and succeed not only by having the required technology, capital and facilities but also by having human resources that are committed to accomplishing their goals (Madiawati \& Pradana, 2016).

Moreover, the recruitment and selection of the right person for the organisation is a result of leadership. If the human resources manager recruits the wrong person, this will be due to their unethical actions because they knew that the organisation required a more capable person than the person who they recruited. This type of issue falls under the criteria of leadership ethics, the implementation of which makes the job a discipline (Lu \& Lin, 2014).

The employees who do not behave according to the set rules and policies are punished or receive penalties from the organisation. Unpredictable behaviour is unacceptable within the organisation; therefore, the company needs to develop rules to ensure employees' discipline (De Roeck \& Farooq, 2018) and that employees maintain the proper performance levels (Kusasih \& Tridayanti, 2020).

\section{LITERATURE REVIEW}

\subsection{Ethical leadership}

Brown, Treviño and Harrison (2005) defined ethical leadership as a 'demonstration of normatively appropriate conduct through personal actions and interpersonal relationships, and the promotion of such conduct to followers through two-way communication, reinforcement, and decision-making'. Furthermore, Resick et al. (2006) defined it as leading the subordinates in a manner that respects their dignity and rights.

Trevino et al. (2000) suggested the dual pillar method of ethical leadership, which differentiates between a moral person who has certain traits (integrity, honesty and trustworthiness), behaviours (does the right things, is open and concerned about 


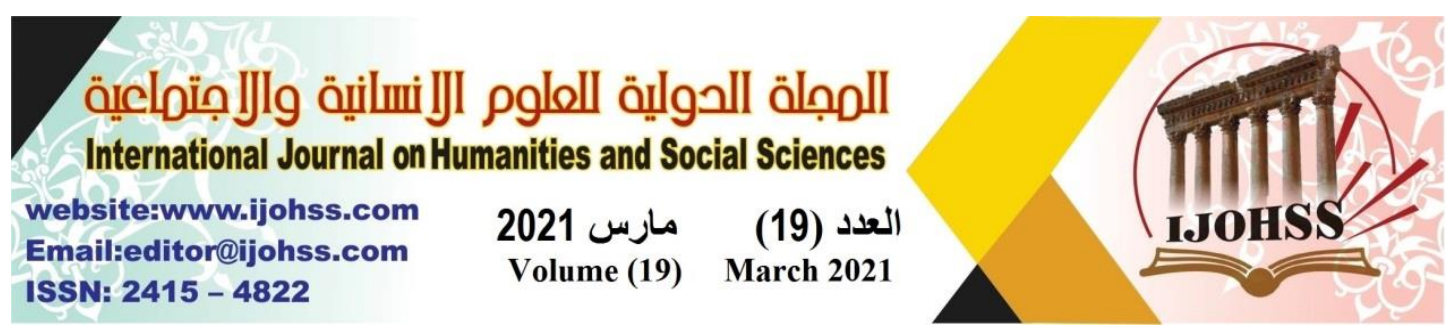

people) and decision-making skills (strong values, fair) and a moral manager who has the following roles:

Ethical role modelling: Ethical managers set a good example for the subordinates to follow on both professional and private levels (Weaver et al., 2005). By observing their leaders' behaviour, subordinates can learn what to do and what not to do. They will copy everything, both moral and immoral, from their leaders (Kaptein, 2002).

Reward and punishment (reinforcement): To ensure the repetition of moral conducts and refrain from immoral conducts, moral leaders must reward appropriate conducts and punish the negative deviations. This will guarantee the commitment of followers (Brown et al., 2005; Lasthuizen, 2008). Grojean et al. (2004) revealed that rewarding behaviours that support ethical standards will help when making ethical decisions and spread the moral culture within the organisation.

Communicating about ethics and values: In this method, the leader influences the moral behaviour of their followers. The leader must disseminate the moral principles and values among the followers, clarify anything necessary to understand the tasks, norms and role expectations and provide them with guidance to complement their actions (de Hoogh \& den Hartog, 2008; Piccolo et al., 2010). Ethical leaders usually encourage their followers to take part in the decision-making process and listen to their suggestions and concerns through mentoring and continuous development (Khuntia \& Suar, 2004). Additionally, they are open (extraverted) and solve their employees' problems (Huberts et al., 2007). Moral leadership values transparency in all behaviours and activities, providing the followers with the reasons behind the decisions (Heres \& Lasthuizen, 2012)

\subsection{Organisational discipline}

There are varying definitions of organisational discipline, and it is an important factor that supports the quality of human resources (Fahlepi, 2020). Some definitions focus on the management actions that encourage employees' compliance with organisational rules and standards, such as Werther and Davis' (1993) definition. Others focus on the employee's awareness and willingness to comply with the regulations and norms of the organisation to improve the quality and amount of work (Elçi \& Alpkan, 2009; Fitria, 2019).

Calhoon (2008) stated the following three distinctive characteristics of discipline: first, it is an action of self-control (adhering to rules); second, discipline is a negative approach (refraining from undesired activities); and third, discipline is a penal approach (punishment for the wrong activities).

\subsection{Ethical leadership and organisational discipline}

Previous studies discussed the impact of leadership and ethical leadership on organisational discipline. Saragih et al. (2018) revealed the positive impact of ethical leadership on Indonesian telecommunication employees' discipline, and Liyas (2017) studied the bank sector and found that leadership had a significant impact on employee work discipline. The influence of leadership on employee discipline was analysed by Fitria et al. (2019), where they discovered a positive, significant impact of leadership on employee discipline. 


\section{المجلة الحولية اللعلور الآنسانية والإمتماعية International Journal on Humanities and Social Sciences}

website:www.ijohss.com

Email:editor@ijohss.com

مارس 2021

(19) العدا (19)

ISSN: $2415-4822$

Volume (19) March 2021

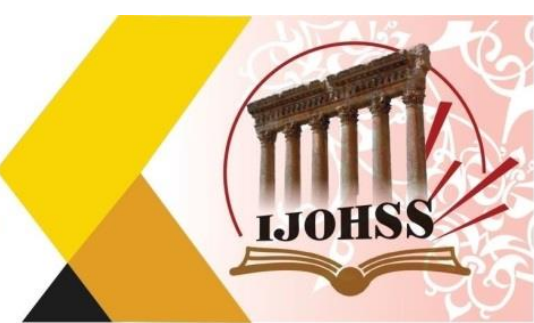

Many studies explored the impact or relationship of ethical leadership on or with organisational variables, such as followers' behavioural outcomes, e.g. job satisfaction and affective commitment (Ghahroodi et al., 2013; Lotfi et al., 2018; Toor and Ofori, 2009; Zhu et al., 2004). Babalola et al. (2018) examined the impact of ethical leadership on workplace conflicts, focusing on relationship, task and process conflicts. Bhana and Bayat (2020) analysed the effect of ethical leadership on employees' effective work practices represented by employees' relationships, performance and behaviour, whereas Kalshoven et al. (2011) examined its effect on organisational citizenship behaviour. In addition, trust and commitment among employees were tested as dependent variables for ethical leadership by Mohiuddin and Hossain (2016) and Van den Akker et al. (2009). Ekriem (2012) found that the levels of applying total quality management were influenced by ethical leadership behaviours in hospitals. The impact of ethical leadership on moral community and change was analysed by Sama and Shoaf (2007), Neubert et al. (2009) and Ali and Altaei (2018).

The following hypotheses are suggested based on the literature review to examine the proposed impact of ethical leadership on organisational discipline:

H1: Ethical role modelling has an impact on the organisational discipline.

$\mathrm{H}$ 2: Reward and punishment have an impact on the organisational discipline.

H3: Communicating about ethics and values has an impact on the organisational discipline.

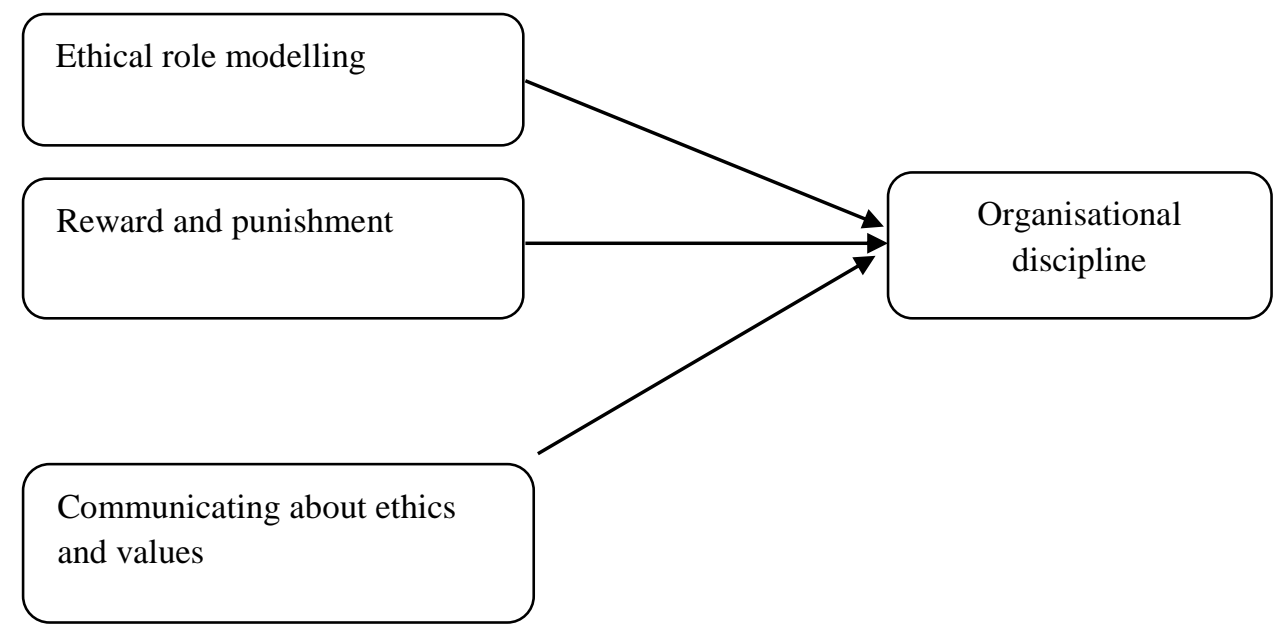

Figure 1: Proposed theoretical model 


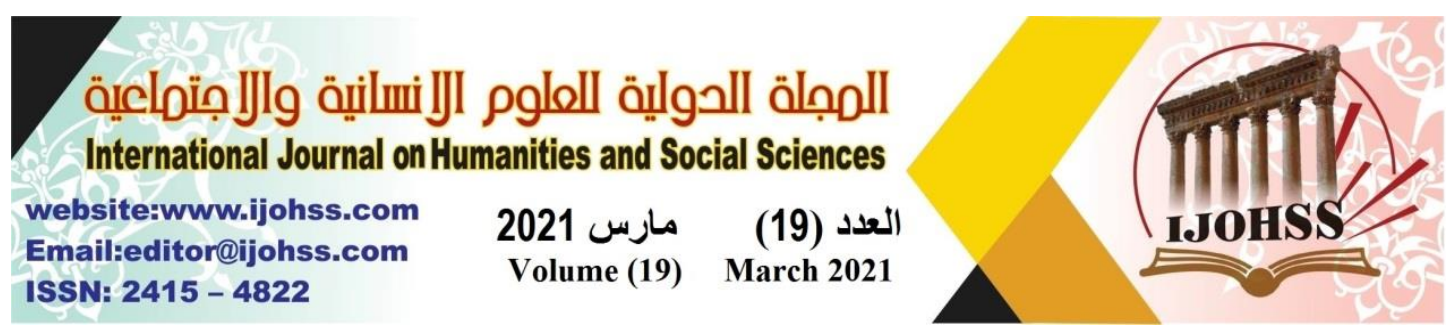

\section{METHODOLOGY}

The aim of the current study is to investigate the impact of ethical leadership on organisational discipline in the telecommunication industry in the Sultanate of Oman, focusing on Omantel, which is the first and largest telecommunication mobile service provider in Oman (Omantel website, 2020). The study sample consisted of employees and management at Omantel in the Dhofar region, and the total sample size consisted of 150 managers and employees. One hundred questionnaires were randomly distributed to respondents over two sessions. In the first session, the management of the Omantel Salalah branch only approved distributing 50 questionnaires for confidentiality; however, the researcher then got approval to distribute the rest of the sample. All distributed questionnaires were completed by the respondents; therefore, they were valid for the statistical analysis. The survey method that was used to collect the data was distributing questionnaires to the respondents during official working hours at Omantel Salalah. The questionnaire consisted of the following three sections: the first section included demographic data about the participants; the second section included questions about ethical leadership based on Brown et al. (2005); and the third section included questions about organisational discipline based on Alotaibey (2013). The Likert 5-points scale was used to format the survey questions, and the answers were ranked from (1) strongly disagrees to (5) strongly agree. The data obtained from the survey was analysed using SPSS 25.0 software. Most statistical tests, such as frequencies, reliability analyses, correlation and multiple regression analyses, were used independently.

\subsection{Respondents}

The frequency and percentage were used for the demographic variables of the respondents in the current study, as shown in Table I. Approximately $37 \%$ of respondents were females, which reveals Omantel's aim to recruit females. Recruiting young employees is another strategy that was revealed from the high percentage of employees $(70 \%)$ who were less than 35 years old, which offers staffing opportunities for graduates who have up-to-date knowledge. Most of the respondents were from managerial staff who were aware of moral issues and practices. 


\section{المجلة اللحولية اللملوم الآنسانية والامتماعية}

International Journal on Humanities and Social Sciences website:www.ijohss.com Email:editor@ijohss.com مارس 2021 (19) العدا ISSN: $2415-\mathbf{4 8 2 2}$

Volume (19) March 2021

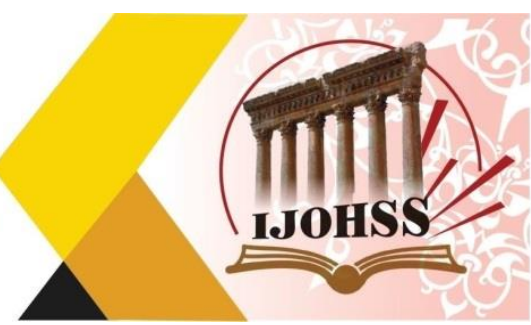

Table I: Frequencies of Demographic Variables

\begin{tabular}{|c|c|c|c|}
\hline Variables & Categories & Number & Percentage \\
\hline \multirow{2}{*}{ Gender } & Male & 63 & 63.0 \\
\hline & Female & 37 & 37.0 \\
\hline \multirow{4}{*}{ Age (years) } & Less than 25 & 14 & 14.0 \\
\hline & $25-35$ & 56 & 56.0 \\
\hline & $35-45$ & 20 & 20.0 \\
\hline & Above 45 & 10 & 10.0 \\
\hline \multirow{3}{*}{ Position } & Employee & 42 & 42.0 \\
\hline & Supervisor & 37 & 37.0 \\
\hline & Manager & 21 & 21.0 \\
\hline Total & & 102 & $100 \%$ \\
\hline
\end{tabular}

\subsection{Reliability, standard deviation and mean}

Table II shows that all variables in this study have high levels of reliability, as Cronbach's Alpha values were very high, ranging between 0.85-0.94. All dimensions of ethical leadership were available at high levels; the highest one was ethical role modelling (3.97), and the lowest one was reward and punishment (3.68). The discipline of Oman Tel employees was at a high level (3.96), and the standard deviation of all variables was less than 1 , except for discipline, which was slightly more than 1 .

Table II: Mean, Standard Deviation and Cronbach's Alpha

\begin{tabular}{rlccc}
\hline No & \multicolumn{1}{c}{ Variables } & M & SD & Cronbach Alpha \\
\hline 1 & Ethical role modelling & 3.9700 & .62692 & 0.85 \\
2 & Reward and punishment & 3.6800 & .90319 & 0.94 \\
3 & Communicating about ethics and & 3.7400 & .94409 & 0.93 \\
& values & & & \\
4 & Discipline & 3.9550 & 1.07754 & 0.92 \\
\hline
\end{tabular}

\subsection{Correlation}

The correlation among ethical leadership dimensions and discipline was examined using the Pearson test. The results showed a strong, positive, significant relationship between communicating about ethics and values and discipline (.786) at the 0.01 level. Moreover, the correlation between reward and punishment and discipline was low (.197). 


\section{المجلة اللحولية اللملوم الآنسانية والامتماعية}

International Journal on Humanities and Social Sciences

website:www.ijohss.com

Email:editor@ijohss.com

مارس 2021

(19) (لعدا (19)

ISSN: $2415-\mathbf{4 8 2 2}$

Volume (19) March 2021

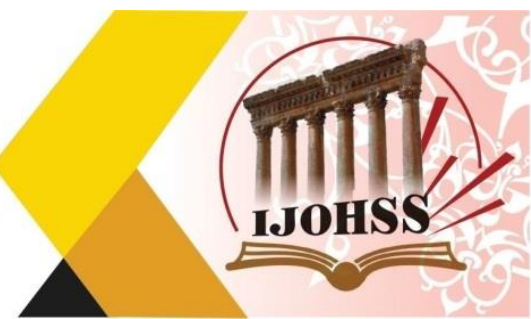

Table III: Correlation Among Ethical Leadership Dimensions and Discipline

\begin{tabular}{|c|c|c|c|c|}
\hline & 1 & 2 & 3 & 4 \\
\hline Ethical role modelling & 1 & & & \\
\hline Reward and punishment & .085 & & & \\
\hline $\begin{array}{l}\text { Communicating about ethics and } \\
\text { values }\end{array}$ & $.307^{* *}$ & $.209^{*}$ & & \\
\hline Discipline & $.369^{* *}$ & $.197^{*}$ & $.786^{* *}$ & 1 \\
\hline
\end{tabular}

\subsection{Multiple regression analysis}

A multiple regression analysis was used to test the hypothesis. Table IV shows that role modelling has a significant impact on discipline $(\mathrm{B}=.242, \mathrm{~T}=2.174, \mathrm{P}<0.05)$, which means that we can accept the $\mathrm{H} 1$ hypothesis. As reward and punishment had no impact on organisational discipline, $\mathrm{H} 2$ was rejected $(\mathrm{B}=.042, \mathrm{~T}=.558, \mathrm{P}>0.05) . \mathrm{H} 3$ was accepted to confirm the effect of communicating about ethics and values on organisational discipline, as its statistical values were $\mathrm{B}=.834, \mathrm{~T}=10.989, \mathrm{P}<0.001$. The R-Square value for the total ethical leadership's facets was about $64 \%$ of organisational discipline among the sample members, and the F value (42.04) indicated the validity of the study model at a significant level (0.001).

Table IV: Multiple Regression Analysis

\begin{tabular}{|c|c|c|c|c|}
\hline Independent Variables & B & $\mathbf{R}$ & $\mathbf{R}^{2}$ & $\mathbf{F}$ \\
\hline Ethical role modelling & .242 & $2.174 *$ & & \\
\hline Reward and punishment & .042 & .558 & & \\
\hline $\begin{array}{l}\text { Communicating about } \\
\text { ethics and values }\end{array}$ & .834 & $10.989 * * *$ & & \\
\hline Discipline & & .799 & .639 & $42.04 * * *$ \\
\hline
\end{tabular}

\section{DISCUSSION}

The findings of the statistics show that ethical leadership dimensions (ethical role modelling, reward and punishment and communicating about ethics and values) were available at high levels, i.e. the managers and employees of Omantel have a good awareness of ethical practices and rules, which in turn, builds a moral and healthy environment among Omantel staff. This result is consistent with Saragih et al. (2018), who found high levels of ethical leadership in an Indonesian telecommunication company. Similarly, discipline among Omantel staff and management was found at high levels. Additionally, the results showed a strong, positive correlation between ethical leadership and organisational discipline. These findings suggest that if the organisations' managements want to increase organisational discipline, they should follow ethical leadership in the workplace.

The current findings have several implications for leaders who aim to create a work environment where employees can work according to the regulation rules, which will cause their behaviours to match the organisational discipline. Specifically, leaders could serve as ethical role models for employees to demonstrate the desired levels of 


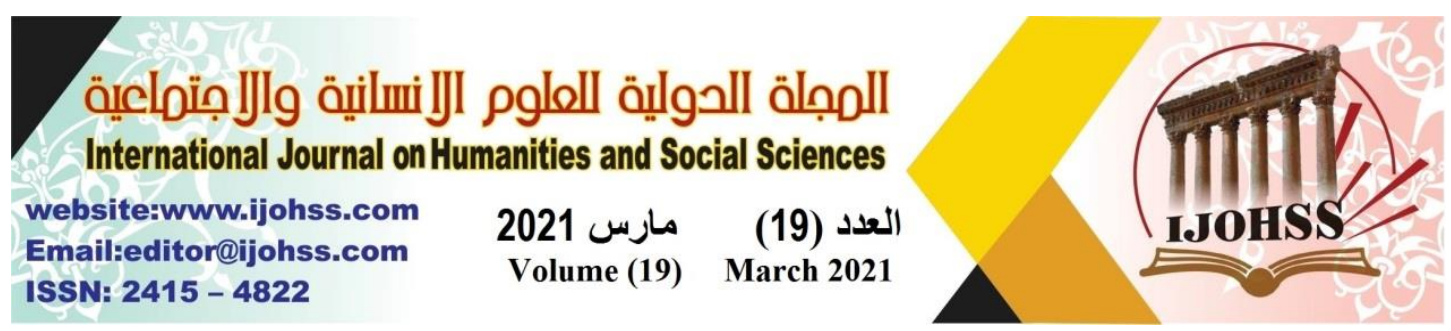

organisational discipline. When the employees have a high orientation toward work ethics, through communication with their ethical leaders, they feel that they are responsible and obligated to perform their job. Therefore, the leaders' ethics affect employee discipline at the Indonesian Telecommunication Company (Saragih et al, 2018). Ethical leadership at all levels within the organisation increase commitment to the organisation and create an overall ethical climate (Kottke \& Pelletier, 2013; RuizPalomino et al., 2011)

Zoghbi-Manrique-de-Lara and Suárez-Acosta (2014) found a positive relationship between workers' perceptions of ethical leadership and interactional justice towards colleagues. Ethical leadership was found to be positively related to the ethical behaviour of employees (Koh \& Boo, 2001). Tu and Lu (2013) confirmed the positive relationship between ethical leadership and innovative behaviours of workers. Moreover, Rubin et al. (2010) examined how ethical leadership behaviours helped 96 leaders to get promoted.

To support the employees' discipline, leaders must remain in contact with their followers through effective and continuous communication, dialogues and discussions. Van den Akker et al. (2009) found that communicating using ethics and values was important to keep the employees' trust. Additionally, communicating using ethics and values helps leaders to handle any problems and avoid the consequences from negative repercussions (Yukl, 2013). Moreover, it boosts collaborative work with management to increase job effectiveness (Mohrman et al., 1995).

\section{LIMITATIONS AND FUTURE STUDIES}

This study has several limitations, such as other aspects that need to be addressed in future studies. This study only examines the effect of ethical leadership on organisational discipline; therefore, future studies may examine other constructs, such as work justice, quality of work life and organisational culture. Second, as this study follows the quantitative approach for examining moral and behavioural variables, future researchers may try to use both quantitative and qualitative approaches to get more reliable results. Third, as this study is limited to the telecommunication sector, future researchers could examine other sectors, such as the manufacturing, education and medical sectors, especially during the COVID-19 pandemic. Despite the above limitations, the findings of this study contribute significantly to the literature of ethical leadership and organisational discipline.

\section{CONCLUSION}

The current study revealed that ethical leadership factors are present at high levels at Omantel. Additionally, organisational discipline is available at high levels among Omantel employees and management. Ethical role modelling and communicating about ethics and values has a significant impact on organisational discipline, whereas reward and punishment does not affect organisational discipline at Omantel. 


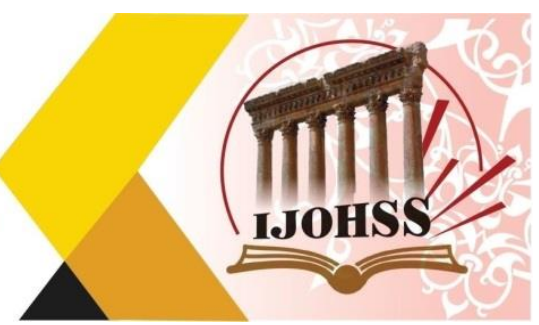

\section{References}

1. Ali, S., \& Altaei, A. (2018). Building a Model for senior administrative leader's ethics for establishing organizational change- Analytical Study on a Sample of Iraqi Technical Universities, Albahith Journal of Human and Social Sciences, Vol. 34, June, pp. 1-28.

2. Koh, H. C., \& Boo, E. H. Y. (2001). The link between organizational ethics and job satisfaction: A study of managers in Singapore. Journal of Business Ethics, 29, pp. 305-324.

3. Alshaier, E. (2017). Moral leadership practices and their relationship to the achievement of administrative creativity (Field study on Palestinian universities in the Gaza strip), unpublished Master thesis of business administration, The Islamic University-Gaza.

4. Babalola, M. T., Stouten, J., Euwema, M. C., \& Ovadje, F. (2018). The Relation Between Ethical Leadership and Workplace Conflicts: The Mediating Role of Employee Resolution Efficacy. Journal of Management, 44(5), pp. 2037-2063.

5. Bhana, A., \& Bayat, M. S. (2020). The relationship between ethical leadership styles and employees effective work practices. International Journal of Higher Education, 9(4), pp. 128-137.

6. Yukl, Gary. (2013). Leadership in Organizations. 8th ed. Boston: Pearson.

7. Rubin, R., Dierdorff, E., \& Brown, M. (2010). Do Ethical Leaders Get Ahead? Exploring Ethical Leadership and Promotability. Business Ethics Quarterly, 20(2), pp. 215-236.

8. Heres, L. \& Lasthuizen, K. (2012). What's the Difference? Ethical Leadership in Public, Hybrid and Private Sector Organizations, Journal of Change Management, Vol. 12 No.4, pp. 441-466.

9. Brown, M. E., \& Treviño, L. K. (2006). Ethical leadership: A review and future directions. Leadership Quarterly, 17(6), pp. 595-616.

10. Brown, M. E., Treviño, L. K., \& Harrison, D. A. (2005). Ethical leadership: A social learning perspective for construct development and testing. Organizational Behavior and Human Decision Processes, 97, pp. 117-134.

11. Butt, A., Butt, I., \& Ayaz, M. (2016). Impact of Ethical Leadership on Organizational Performance and Mediating Role of Corporate Social Responsibility: Evidence from Banking Sector of Pakistan., International Journal of Management Sciences and Business Research, Vol. 5 No. 6, pp. 2537.

12. Calhoon, A.E. (2008). Discipline in Response to Unacceptable Performance: Hindrance to Access in Organizations. International Journal of Educational Management, 6(4), pp. 394-412.

13. de Hoogh, A. H. B., and D. N. den Hartog. (2008). Ethical and despotic leadership, relationships with leader's social responsibility, top management 


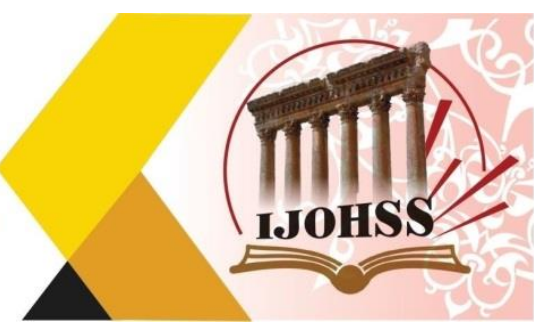

team effectiveness and subordinates' optimism: A multi-method study. Leadership Quarterly 19 (3), pp. 297-311.

14. De Roeck, K., \& Farooq, O. (2018). Corporate social responsibility and ethical leadership: Investigating their interactive effect on employees' socially responsible behaviors. Journal of Business Ethics, 151(4), pp. 923-939.

15. Khuntia, R. and Suar, D. (2004) A scale to assess ethical leadership of Indian private and public sector managers, Journal of Business Ethics, 49(1), pp. 1326.

16. Dradkeh, A., Al-Mutairy, H. (2017). "The Role of Ethical Leadership in Enhancing Organizational Trust Among Principals of Primary Schools in Taif City," Jordanian Journal of Educational Sciences, Vol. 13 No. 2, pp. 223-237.

17. Ruiz-Palomino, P., Ruiz-Amaya, C., \& Knörr, H. (2011). Employee Organizational Citizenship Behaviour: The Direct and Indirect Impact of Ethical Leadership. Canadian Journal of Administrative Sciences / Revue Canadienne des Sciences de l'Administration, 28(3), pp. 244-258.

18. Ekriem, M. (2012) The Impact of Ethical Leadership Behavioral on Applying Total Quality Management Concept in Libyan Hospitals. Unpublished Doctoral thesis of business administration, Ain Shams University.

19. Elçi, M., and Alpkan, L. (2009). "The impact of perceived organizational ethical climate on work satisfaction," J Bus Ethics, vol. 84 no. 3, pp. 297-311.

20. Fahlepi, R. (2020). Decision Support Systems Employee Discipline Identification Using the Simple Multi Attribute Rating Technique (SMART) Method. Journal of Applied Engineering and Technological Science (JAETS), 1(2), pp. 103-112.

21. Fitria, Y., Sutiyem, S., Trismiyanti, D., \& Suhery,. S. (2019). Identification of the Influence of Leadership and Organizational Culture on Employee Discipline. Advances in Economics, Business and Management Research, volume 97, pp. 726- 733.

22. Ghahroodi, H., Ghazali, M. Z. B. T. S. M., \& Seyed Ghorban, Z. (2013). Examining ethical leadership and its impacts on the followers' behavioral outcomes. Asian Social Science, 9(3), pp. $91-96$.

23. Piccolo, R.F., Greenbaum, R., den Hartog, D.N. and Folger, R. (2010) The relationship between ethical leadership and core job characteristics, Journal of Organizational Behavior, 31(2-3), pp. 259-278.

24. Grojean, M., C. Resick, M. Dickson, and D. Smith. (2004). Leaders, values, and organizational climate: Examining leadership strategies for establishing an organizational climate regarding ethics. Journal of Business Ethics, 55 (3), pp. 223-241.

25. Huberts, L.W.C., Kaptein, M. and Lasthuizen, K. (2007) A study of the impact of three leadership styles on integrity violations committed by police officers, Policing. An International Journal of Police Strategies \& Management, 30(4), pp. 587-607. 


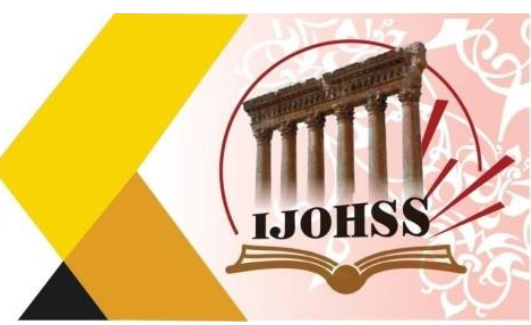

26. Mohrman, S. A., Cohen, S. G., \& Mohrman, A. M. (1995). Designing teambased organizations: New forms for knowledge work. San Francisco: Jossey Bass.

27. Kottke, J. L., \& Pelletier, K. L. (2013). Measuring and differentiating perceptions of supervisor and top leader ethics. Journal of Business Ethics, 113, pp. 415-428.

28. Hassan, S., Wright, B. E., \& Yukl, G. (2014). Does ethical leadership matter in government? Effects on organizational commitment, absenteeism, and willingness to report ethical problems. Public Administration Review, Vol. 74 No. 3, pp. 333-343.

29. Kalshoven, K., Hartog, D., Hoogh, A. (2011). Ethical leadership at work questionnaire (ELW): Development and validation of a multidimensional measure, The Leadership Quarterly, Vol. 22 No.1, pp. 51-69.

30. Kaptein, M. (2002). Guidelines for the development of an ethics safety net. Journal of Business Ethics, 41, pp. 217-234.

31. Zoghbi-Manrique-de-Lara, P., \& Suárez-Acosta, M. A. (2014). Employees' reactions to peers' unfair treatment by supervisors: The role of ethical leadership. Journal of Business Ethics, 122, pp. 537-549.

32. Kusasih, I., and Tridayanti, H. (2020). Influence of Employee Discipline, Compensation and Employee Load on Employee Performance in PT. Tozy Sentosa in Surabaya, Journal of World Conference, Vol. 2 No. 3, pp. 152-168.

33. Lasthuizen, K. (2008). Leading to integrity: Empirical research into the effects of leadership on ethics and integrity. Amsterdam: VU University Amsterdam.

34. Liyas, J. (2017). Pengaruh Kepemimpinan Terhadap Disiplin Kerja Karyawan Pada Pt. Bank Syariah Mandiri, Jurnal Ekonomi Dan Bizins Islam, Vol. 2 No. 2, pp. 1-10.

35. Lotfi Z, Atashzadeh-Shoorideh F, Mohtashami J, Nasiri M. (2018). Relationship between ethical leadership and organisational commitment of nurses with perception of patient safety culture. J Nurs Manag, 26, pp. 726-34

36. Lu, C., \& Lin, C. (2014). The Effects of Ethical Leadership and Ethical Climate on Employee Ethical Behavior in the International Port Context. Journal of Business Ethics, 124(2),pp. 209-223.

37. Madiawati, P. N., \& Pradana, M. (2016). Celebrity and halal certificates factors influence on customers' buying interest. Актуальні проблеми економіки, (3), pp. 109-116.

38. Mayer, D. M., Kuenzi, M., Greenbaum, R., Bardes, M., \& Salvador, R. B. (2009). How low does ethical leadership flow? Test of a trickle-down model. Organizational Behavior and Human Decision Processes, 108(1), pp. 1-13.

39. Mendonca, M. (2001). Preparing for ethical leadership in organizations. Canadian Journal of Administrative Sciences, 18, pp. 266-276.

40. Mohiuddin, G., \& Hossain, M. (2016). Ethical Leadership: Its Issues and Impacts in Organization. International Journal of Islamic Management and Business, 2(2). 


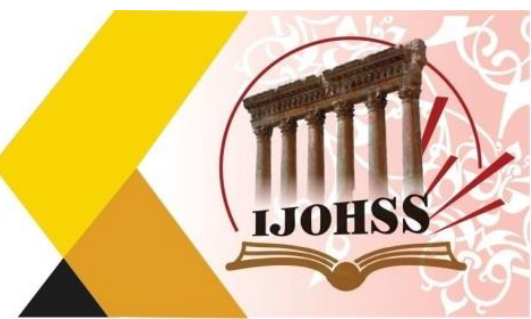

41. Neubert, M., Carlson, D., Kacmar, K., Roberts, J., \& Chonko, L. (2009). The Virtuous Influence of Ethical Leadership Behavior: Evidence from the Field. Journal of Business Ethics, Vol. 90 No. 2, pp. 157-170.

42. Omantel Co. about. Omantel, available at: https://www.omantel.om/About / (accessed 20 January 2020). 2020.

43. Rantika, S. D., \& Yustina, A. (2017). "Effects of Ethical Leadership On Employee Well-being: The Mediating Role of Psychological Empowerment." Journal of Indonesian Economy and Business, vol. 32 No. 2, pp. 121-137.

44. Resick,C. J., Hanges, P. J., Dickson, M. W., Mitchelson, J. K.,(2006). "A Cross-Cultural Examination of the Endorsement of Ethical Leadership", Journal of Business Ethics, Vol.63, pp. 345-359.

45. Riaz, A. \& Zaman, S. (2018). Impact of Ethical Leadership on Organizational Cronyism through Mediating Role of Ethical Culture and Moderating Role of Leader Member Exchange, Pakistan Journal of Commerce and Social Sciences, Vol. 12 No. 3, pp. 831-850.

46. Sama, L. M., \& Shoaf, V. (2007). Ethical leadership for the professions: Fostering a moral community. Journal of Business Ethics, Vol. 78, pp. 39-46.

47. Saragih, R., Fakhri, M., Pradana, M., Gilang, A., \& Vidjashesa, G. A. (2018). Ethical leadership's effect on employee discipline: Case of an Indonesian telecommunication company. Proceedings of the International Conference on Industrial Engineering and Operations Management, 2018(NOV).

48. Toor, S., \& Ofori, G. (2009). Ethical leadership: Examining the relationships with full range leadership model, employee outcomes, and organizational culture. Springer Journal of Business Ethics, Vol. 90 No. 4, pp. 533 - 547.

49. Treviño, L. K., Hartman, L. P., \& Brown, M. (2000). Moral Person and Moral Manager: How Executives Develop a Reputation for Ethical Leadership. California Management Review, 42(4), pp. 128-142.

50. Van den Akker, L., Heres, L., Lasthuizen, K. M., \& Six, F. E. (2009). Ethical leadership and trust: It's all about meeting expectations. International Journal of Leadership Studies, 5(2), pp. 102-122.

51. Weaver, G. R., Treviño, L. K., \& Agle, B. (2005). "Somebody I Look Up To". Ethical Role Models in Organizations. Organizational Dynamics, 34, pp. 313330.

52. Werther, W. B., \& Davis, K. (1993). Human resources and personnel management. New York: McGraw-Hill.

53. Yang, C. (2014). Does Ethical Leadership Lead to Happy Workers? A Study on the Impact of Ethical Leadership, Subjective Well-Being, and Life Happiness in the Chinese Culture. J Bus Ethics 123, pp. 513-525.

54. Zhu, W., May, D. R., \& Avolio, B. J. (2004). The impact of ethical leadership behavior on employee outcomes: The roles of psychological empowerment and authenticity. Journal of Leadership and Organizational Studies, 11, pp. $16-26$. 